\title{
Body temperature and dehydration rate in adolescents undergoing the Cooper's 12-minute run test
}

\author{
William Alves Lima ${ }^{(1)}$, Yara Bezerra ${ }^{(1)}$, Viviane Soares ${ }^{(1)}$, Iransé Oliveira Silva ${ }^{(1)}$, Grassyara Pinho Tolentino(1), \\ Jairo Teixeira Júnior ${ }^{(1)}$, Margareth Faria ${ }^{(1)}$, Patrícia Espíndola Mota Venâncio(1).
}

\begin{abstract}
Background: During the practice of any physical exercises is produced heat. About $30 \%$ of this heat is transformed into work and the other $70 \%$, distributed to the body, thus increasing the body temperature of the individual. Objective: to identify changes in body temperature and hydration of adolescents classified as physically actives or inactives. Methods: This is a cross-sectional, quantitative, descriptive study with 40 students (13-17 years old) from a private school in Anápolis-GO. The tympanic and forehead body temperature and body mass were measured. The urine produced was then collected and the hydration state was estimated before and after the 12-minute run test, which was used to calculate the $\mathrm{VO}_{2 \max }$. After checking the normality of the data, the paired " $\mathrm{t}$ " test was performed to compare the pre and post-run data and a " $t$ " test for independent samples to compare the groups denominated: active and inactive. Results: there was no significant difference in relation to the temperature pre-and post-test of the Cooper protocol in active and inactive individuals, but the active group had a higher central temperature. The active group presented a greater reduction of body mass and a worse state of dehydration, evaluated by the urine color, and also by the calculation of the rate of sweating. Finally, although both groups received the classification of "weak" regarding aerobic capacity, the active group was significantly superior to the inactive group. Conclusion: the group of actives adolescents presented higher central body temperature, with a higher rate of sweating, due to their greater physical effort (better test performance) and their better training, which can lead to a better body cooling system.
\end{abstract}

Keywords: Physical Fitness; Thermoregulation; Hydration.

\section{INTRODUCTION}

Physical fitness is conceptualized as the ability to perform activities of your daily life without too much fatigue ${ }^{(1)}$. It is composed of physiological and psychosocial variables which help to balance the well-being and lifestyle of the individuals, since a person with a good physical aptitude is more likely to be healthy in the development of hypokinetic diseases ${ }^{(2,3)}$.

In order to maintain or improve physical fitness, it is necessary to practice physical exercises. That is, systematized activities aimed at improving health ${ }^{(4)}$. One of the physiological factors that limits good performance in physical exercises and improvement of physical fitness is thermoregulation, defined as the physiological capacity that the body maintains at ideal temperature ${ }^{(5)}$. The ideal body temperature should remain between $36.1^{\circ} \mathrm{C}-37^{\circ} \mathrm{C}$. The practice of physical activities is one of the variables that remove the body from homeostasis, causing this temperature to reach up to $41^{\circ} \mathrm{C}^{(6)}$.

During the practice of any physical exercises is produced heat. About $30 \%$ of this heat is transformed into work and the other $70 \%$, distributed to the body, thus increasing the body temperature of the individual. To occur the reduction in body temperature it is necessary to use one of the means for heat loss. Among these, we have convection, conduction, radiation and evaporation. The most used and efficient is the evaporation ${ }^{(6)}$, in addition to these means, the blood flow also controls the loss of heat, as the measure of the central heat increases and this blood flow is diverted to the $\operatorname{skin}^{(7)}$. However, among the aforementioned means, evaporation is the most efficient way for heat loss. This occurs when the sweat glands transfer the "water" to the exogenous environment (without the loss of cytoplasm or organelles) so that this water evaporates and carries with it the heat of the body surface ${ }^{(8)}$.

The study of Gaspar et al. ${ }^{(9)}$ demonstrates that triathlon athletes show a drop in yield because they have a high production rate of sweating and poor water replenishment. From this premise, it is of great importance a good hydration for the practice of systematized physical activities.

Thus, it is necessary to study the aerobic capacity and thermoregulation related to the changes that occur during the practice of strenuous physical exercises. Thereby, the present study aims to identify changes in body temperature and hydration in adolescents classified as physically active or inactive. 


\section{METHODOLOGY}

This is a cross-sectional, quantitative, descriptive study. The convenience sample consisted of 40 adolescent students aged 13 to 17 years old, from a private school in the city of Anápolis-GO. The study used the standards for conducting research on humans, resolution no 466 of December 12, 2012 of the National Health Council and was approved by the Research Ethics Committee of the Centro Universitário de Anápolis - UniEVANGÉLICA, protocol number 2.147.331.

The invitation was made to the adolescents, sending the necessary documents to the parents and minors. After they signing the free and informed form the tests were started. In this way, the volunteer received a folder explaining how the tests would be like and how they should behave before, during and after the test. There were also directives regarding the type of clothing and footwear.

Then, was measured the body mass through a Filizola ${ }^{\circledR}$ (Filizola LTDA, Recife, PE, Brazil) stadiometer ${ }^{(10)}$. The body mass was measured as soon as the individual arrived (after the first collection of urine) and raised in the scale again about 15 minutes after the end of the run, shortly after the second collection of urine. On average, there was a time interval of 58 minutes between the first and second weighing.

The comparison of pre and post effort body mass can be used to verify rapid changes in the hydration of people submitted to a systematic effort ${ }^{(11)}$. This methodology is based on the estimation that 1 gram of lost body mass equals $1 \mathrm{ml}$ of lost liquid ${ }^{(12)}$.

For the estimation of $\mathrm{VO}_{2 \max }$. was applied the 12-minute running test proposed by Cooper ${ }^{(13)}$, measuring the distance traveled in this period of time. This test was performed on an athletic track, counting the number of laps in the established perimeter with known distance. The measurements of the perimeter, and the distance of the incomplete turns were measured with a $50 \mathrm{~m}$ (Brasfort ${ }^{\circledR}$ ) (Brasfort LTDA, São Paulo, SP, Brazil) line. All measurements were made by a single evaluator accompanied by the annotator.

In order to quantify the volume of water ingested, volunteers were asked about the doses of water/infusions/teas and industrialized beverages consumed daily. The water counted via questionnaire was designated for the purposes of the analysis as ingested water. A food recall was not quantified to estimate the percentage of liquid per food, eaten in the volunteers' regular diet. It was also asked about the use of dietary supplements and medicines.

For the day of the run test they were asked to maintain their natural routine of fluid ingestion. On the day agreed for the run test, as the volunteers arrived, they completed the anamnesis and the water ingestion questionnaire, were weighed and had their body temperature measured through a G-Tech ${ }^{\circledR}$ digital clinical thermometer with infrared sensor, being this one used to measure the internal temperature of the ear and the forehead, before and after the run test. The ambient temperature on the day of the test was at $26 \circ \mathrm{C}$ at 9am (time that the run was started), with relative air humidity being at $58 \%$. These conditions were measured with a Thermo Hygrometer ICEL model HT-208.

Urine was collected in a sterilized Erlenmeyer, with a capacity of up to $500 \mathrm{~mL}$, as soon as the volunteer completed the anamnesis (about 8:30 am). At this point he was invited to drink a glass of $250 \mathrm{ml}$ of water. After the race, the volunteer waited in the shadow for about 15 minutes to promote a return to calm and, then, the urine was collected again. It had to be a minimum volume of $50 \mathrm{~mL}$, and during this time the volunteers did not hydrate. After each collection the urine was compared to a colorimetric scale for the determination of the levels of hydration developed by Armstrong et al. ${ }^{(14)}$.

The percentage of dehydration was calculated from the difference between the body mass pre and post-exercise: Percentage of dehydration $=[($ Difference between initial and final body mass (in $\mathrm{kg}$ )) - urinary volume after training (in L))] / initial body mass $(\mathrm{kg}) \times 100^{(15)}$. The rate of sweating, expressed in L/hour of exercise, was calculated from the equation proposed by Horswill ${ }^{(16)}$ : rate of sweating = [initial body mass $(\mathrm{kg})+$ water ingestion $(\mathrm{L})]$ - [final body mass al $(\mathrm{kg})+$ urinary volume $(\mathrm{kg})]$ / time $(\mathrm{min}) \times 60$.

For the analysis of the data the volunteers were separated into two groups: Actives- those who made up the school's Handball or Basketball team; Inactives - those who did not participate in physical education and were not included in another practice of systematized physical activity. The descriptive analysis of the data was presented through mean, standard deviation, simple frequency and percentage. The Shapiro-wilk test was performed through which the normality of the data was verified. A paired T-test was then performed to compare pre and post test and a t-test for independent samples to compare between groups. SPSS 20.0 software was used, adopting a level of significance of $p \leq 0.05$.

\section{RESULTS}

As a result of the application of the questionnaire, $53.8 \%$ of the sample consumed $500 \mathrm{~mL}-1000 \mathrm{~mL}$ of water per day (Table 1), and the European Food Security Agency ${ }^{(17)}$ recommended the ingestion of $2.5 \mathrm{~L} /$ day of water for male adolescents and 2 L/day for females, thus demonstrating that the sample was not hydrating correctly. Soon after, the ingestion of soft drinks/teas was quantified and was obtained that $79.5 \%$ of the evaluated ones did not ingest any of the analyzed drinks. It was also identified that $89.7 \%$ of those evaluated did not drink any sports drinks (isotonic), since, if consumed in excess, they can make it difficult to lose weight, increase blood pressure and overload the kidneys. Thus, analyzing the results, it can be noticed that the sample studied performs little ingestion of any type of liquid. 
When comparing the water ingestion between active and inactive groups it was possible to verify that the active group consumes about $300 \mathrm{~mL}$ more water per day than the inactive group (data not shown in Table), which is relatively small this difference, although statistically significant. The ingestion of so little water refers to the concern with the ingestion of dietary supplements. However, only five individuals (all in the active group) reported using food supplements (two reported using creatine, another two whey protein, and 1 reported using maltodextrin). Regarding medication use, only one individual reported regular use of antihistamine (inactive group) and another two (active group) reported being treated with roacutan ${ }^{\circledR}$ (data not shown in table).

The difference in physical condition between the so-called active and inactive groups is explicit (Table 2) by identifying that the actives ran an average of $389 \mathrm{~m}$ more than the inactive ones in the same 12-minute period. This represents almost an extra lap on the track. However, both groups present a bad aerobic condition. It is only possible to point out that the $\mathrm{VO}_{2 \max }$. of the active group is $25.81 \%$ higher than the inactive group.

Table 2 also shows the difference between active and inactive individuals regarding body temperature. Thus, it can be observed that the temperature averages of the Pre and Post run test were not significantly different, even though there was a different physical condition between the groups. However, the tympanic temperature was visually lower when compared to forehead temperature in the two groups analyzed, but this difference was not significant.

When compared to the temperature between the two groups, the active group presented, in a significant way, a greater tympanic heating, both in the pre and post test. The same did not occur to the forehead temperature in any of the analyzed moments.

On the other hand, when the dissipation of the heat produced by the production of sweat was analyzed, was obtained the data of the pre and post-run body mass. With this it is possible to notice that the body mass of the inactive group reduced on average $100 \mathrm{~g}$, while that of the active group reduced $360 \mathrm{~g}$, on average, being this significant reduction only for the active group. This indicates that heat dissipation through sweating does not actually promote a significant reduction in body mass, but with a significant difference between active and inactive, in which the active group produced about three and a half times more sweat.

Table 1- Descriptive Analysis of the “Quantification of Daily Ingestion of Liquids” questionnaire.

\begin{tabular}{|c|c|c|c|c|c|}
\hline \multicolumn{2}{|c|}{ Water Ingestion } & \multicolumn{2}{|c|}{ Soft drinks and teas Ingestion } & \multicolumn{2}{|c|}{ Sports Drink Ingestion } \\
\hline$\leq 200 \mathrm{ml}$ & $12.80 \%$ & None & $79.50 \%$ & None & $89.7 \% *$ \\
\hline $200-500 \mathrm{ml}$ & $12.80 \%$ & One cup & $0 \%$ & $\leq 200 \mathrm{ml}$ & $7.70 \%$ \\
\hline $500-1000 \mathrm{ml}$ & $53.80 \%$ & Two cups & $12.80 \%$ & $200-500 \mathrm{ml}$ & $2.60 \%$ \\
\hline $1000-1500 \mathrm{ml}$ & $17.90 \%$ & Three cups & $2.60 \%$ & $\geq 500 \mathrm{ml}$ & $0 \%$ \\
\hline$\geq 1500 \mathrm{ml}$ & $2.60 \%$ & Four cups & $5.10 \%$ & $\geq 1000 \mathrm{ml}$ & $0 \%$ \\
\hline TOTAL & $100 \%$ & TOTAL & $100 \%$ & TOTAL & $100 \%$ \\
\hline
\end{tabular}

Note: *statistic significance

Table 2- Comparative analysis of variables between trained and untrained individuals.

\begin{tabular}{|c|c|c|}
\hline Variables & INACTIVES $(n=23)$ & ACTIVES ( $n=17)$ \\
\hline Pre-tympanic temperature $\left({ }^{\circ} \mathrm{C}\right)$ & $33.49 \pm 3.78$ & $35.92 \pm 0.49+$ \\
\hline Post-tympanic temperature $\left({ }^{\circ} \mathrm{C}\right)$ & $33.8 \pm 3.40$ & $35.35 \pm 1.53+$ \\
\hline Pre-forehead temperature $\left({ }^{\circ} \mathrm{C}\right)$ & $36.03 \pm 0.69$ & $36.00 \pm 0.67$ \\
\hline Post-forehead temperature $\left({ }^{\circ} \mathrm{C}\right)$ & $36.1 \pm 1.07$ & $36.08 \pm 0.99$ \\
\hline Pre-body mass (kg) & $65.20 \pm 13.40$ & $64.10 * \pm 9.49$ \\
\hline Post-body mass (kg) & $65.10 \pm 13.41$ & $63.74 \pm 9.22+$ \\
\hline Pre-urine & $1.17^{*} \pm 2.39$ & $3.31 * \pm 2.71+$ \\
\hline Post-urine & $3.60 \pm 2.20$ & $5.00 \pm 2.42+$ \\
\hline Distance traveled (m) & $1616.9 \pm 333.18$ & $2005.9 \pm 243.12 \dagger$ \\
\hline $\mathrm{VO}_{2 \max }(\mathrm{mL} / \mathrm{kg} / \mathrm{min})$. & $24.86 \pm 7.43$ & $33.51 \pm 5.40+$ \\
\hline
\end{tabular}

Note: $n=$ number of subjects per group; * represents a significant difference between pre and post test; + represents a significant difference between the active and inactive groups. 


\section{DISCUSSION}

The studied sample has as one of the negative factors a low water consumption, both between active and inactive. The interesting fact is that they have stated that they do not compensate for this inadequate water ingestion with the consumption of soft drinks and other industrialized drinks, since these can favor the development of chronic diseases and also lead to a reduction in physical performance ${ }^{(18)}$. Adequate water consumption is essential for a number of natural biological reactions in the human body. Water ingestion may be inversely related to the volume of sugary drinks and other fluid ingress ${ }^{(19)}$. Water still has a key role in facilitating the transport of substances into the kidneys so that they can be eliminated, and the low water consumption combined with the ingestion of protein supplements may favor the development of kidney stones ${ }^{(20)}$.

A reduced amount of body water can still hinder the body's cooling system through sweating. It is well known that repeated sessions of vigorous physical activities result in hemodilution ${ }^{(21)}$ due to the expansion of plasma volume ${ }^{(22)}$. However, it is unclear whether moderate-intensity physical activity may result in plasma volume expansion. It has recently been discovered that strenuous physical exercise training expands not only blood plasma but also water within the exercised muscles ${ }^{(23)}$. This indicates that stimulating the regular practice of moderate to high intensity physical activities may induce a greater water ingestion, converting individuals to a better hydration profile.

As the active group produced a better performance in the run, its central temperature (tympanic temperature), consequently increased more, which led to a greater production of sweat, causing a greater reduction of body mass, due to dehydration and, a most representative darkening of urine. As the ear temperature represents more central temperatures relative to the carotid blood that bathes the hypothalamus and the temperature of the forehead represents the peripheral temperature, which is the one deviated to eliminate the heat produced by the practice of physical exercises ${ }^{(24,25)}$, and it is natural that those who have tried harder, raise the central temperature higher, while the peripheral temperature is more susceptible to climatic influences.

Vechiato and Costa(15) evaluated the percentage of dehydration of triathlon athletes, which resulted in a reduction in the percentage of body mass of the individuals, and the mean loss of $2.2 \pm 0.7 \%$, placing these individuals in a state of minimal dehydration. In the present study, the loss was only $0.04 \%$ between the inactive and $0.23 \%$ for the active, which characterizes that the 12 minutes test did not generate any type of shock in its state of hydration. However, it must take into consideration that the evidence analyzed by Vechiato and Costa ${ }^{(15)}$ had an average duration of 78 minutes. As the duration of effort in the present study was only $15.4 \%$ of that study, it was expected that those evaluated in the present study presented at least $15 \%$ of the dehydration percentage of triathletes. However, the actives dehydrated
$10 \%$ of the said triathletes dehydrated, whereas the inactive did not reach $2 \%$ of said dehydration rate. This express the low intensity of the effort they produced. In order to avoid a misinterpretation of the data presented above, the rate of sweating was calculated, in which it was detected that for the inactive group it was 1,275 L/h and 1,405 L/h for the active group, which is in agreement with the cited results per Vechiato and Costa ${ }^{(15)}$. This shows that the weight lost is irrelevant when taking into account the amount of urine produced.

In another study related to hydration and aerobic and anaerobic exercises ${ }^{(26)}$ have been reported significant differences between weight loss in aerobic individuals up to $0.8 \mathrm{~kg}$, but it is evident that analyzing only the reduction of body mass without the respective sweating rate is contradiction.

Analyzing the color of the urine according to the parameters indicated by Perrone and Mayer ${ }^{(27)}$, the adolescents in the inactive group were, in the pretest, classified as "well hydrated" and post-test as "mild hypohydration". Meanwhile, active group components presented "mild hypohydration" and progressed to "moderate hypohydration" with the test. According to Alvira et al. ${ }^{(28)}$, adolescents usually present themselves with insufficient hydration, especially those that are insufficiently active. This underscores the importance of an educational process on adequate hydration and how much regular physical activity can favor the need to hydrate.

By culminating in aerobic capacity, Bergamasco et al. ${ }^{(29)}$ measured the $\mathrm{VO}_{2 \text { max. }}$ in handball university athletes and obtained, as a result, that of the 10 athletes analyzed, the average for the $\mathrm{VO}_{2 \text { máx }}$ was $23.88 \mathrm{~mL} / \mathrm{kg} / \mathrm{min}$., which was in agreement with the very low $\mathrm{VO}_{2 \text { max }}$ detected in the present study. However, the volunteers of the active group presented better results $(33.41 \mathrm{~mL} / \mathrm{kg} / \mathrm{min})$ than those cited in the present study. But regardless of this, there is an emerging need for training to improve the $\mathrm{VO}_{2 \text { máx. }}$ in order to achieve a better sports performance and also to ensure a better health development, both in the motor system and in the improvement of the cardiorespiratory system.

\section{CONCLUSION}

Through the research, it was concluded that the active individuals present significantly higher internal temperature, with a greater reduction of body mass after the test, resulting in a greater percentage of dehydration and a higher rate of sweating. Finally, although both groups present a bad aerobic condition the active group denotes a higher aerobic capacity.

\section{AUTHOR'S CONTRIBUTION \\ WAL: Introduction and Discussion; YB: Data Collect; VS: Statistical Analysis; IOS: Elaboration of the methodology and feasibility of the project; GPT: Literature review and discussion review; JTJ: Organization of results; MF: General Article Review; PEMV: General Article Review.}

\section{CONFLICTS OF INTEREST}

The authors declare that there was no conflict of interests. 


\section{REFERENCES}

1. Guedes DP, Guedes JERP. Atividade física, aptidão física e saúde. Revista Brasileira de Atividade Fisica e Saude. 1995;1(1):18-35.

2. Matsudo S, Araújo TL, Matsudo VKR, Andrade DR, Valquer W. Nível de atividade física em crianças e adolescentes de diferentes regiões de desenvolvimento. Revista Brasileira de Atividade Física \& Saúde. 2012;3(4):14-26.

3. Silverman MN, Deuster PA. Biological mechanisms underlying the role of physical fitness in health and resilience. Interface focus. 2014;4(5):1-12.

4. Myers J, McAuley P, Lavie CJ, Despres JP, Arena R, Kokkinos P. Physical activity and cardiorespiratory fitness a major markers of cardiovascular risk: their independent and interwoven importance to health status. Progress in cardiovascular diseases. 2015;57(4):306-314.

5. Charkoudian N. Skin blood flow in adult human thermoregulation: how it works, when it does not, and why. Mayo Clinic Proceedings. Elsevier. 2003:78(5):603-12.

6. Houdas Y, Ring EFJ. Human body temperature: its measurement and regulation. Springer Science \& Business Media. 2013

7. Charkoudian N. Mechanisms and modifiers of reflex induced cutaneous vasodilation and vasoconstriction. Journal of Applied Physiology. 2010;109(4):1221-8.

8. Johnson JM, Kellogg DLJ. Thermoregulatory and thermal control in the human cutaneous circulation Front. Biosci. 2010;2:825-53.

9. Gaspar AM, Leal CDS, Millan RC, Silveira JQ. Avaliação da taxa de sudorese durante treinos leves de triatletas profissionais. RBNE-Revista Brasileira de Nutrição Esportiva. 2016;10(58), 418-28.

10. Marfell-Jones MJ, Stewart A, de Ridder J. International standards for anthropometric assessment. 2012.

11. Cirne MR, Mendes ACR. Avaliação do estado de hidratação da equipe de atletismo (corrida de rua) da polícia da Bahia durante os treinamentos na cidade de Salvador, BA. Lecturas: Educación física y deportes. 2011;16(161).

12. Cheuvront SN, Sawka MN. Avaliação da hidratação de atletas. Sports Science Exchange. 2006;18(2),1-6.

13. Cooper KH. Aerobics. New York: Bantam Books. 1968.

14. Armstrong LE, Maresh CM, Castellani JW, Bergeron MF, Kenefick RW, Lagasse KE, Riebe D. Urinary Indices of Hydration Status. International journal of sport nutrition. 1994;4(3):265-79.

15. Vechiato T, Costa TNF. Avaliação do estado de hidratação e ingestão hídrica em praticantes de triatlo. Revista Brasileira de Nutrição Esportiva. 2016;10(57):250-9.

16. Horswill CA. Effective fluid replacement. International Journal of Sport Nutrition. 1998;8(2):175-295.
17. EFSA - European Food Safety Authority Scientific Opinion on Dietary Reference Values for water EFSA Panel on Dietetic Products, Nutrition, and Allergies (NDA). EFSA Journal. 2010; 8(3):1459.

18. Greenwood DC, Threapleton DE, Evans CEL, Cleghorn CL, Nykjaer C, Woodhead C, Burley VJ. Association between sugar-sweetened and artificially sweetened soft drinks and type 2 diabetes: systematic review and dose-response meta-analysis of prospective studies. British Journal of Nutrition. 2014;112(5),725-34.

19. Stookey J, Constant F, Gardner C, Popkin B. Replacing sweetened caloric beverages with drinking water is associated with lower energy intake. Obesity (Silver Spring). 2007;15(12): 3013-22.

20. Obi Y, Qader H, Kovesdy CP, Kalantar-Zadeh K. Latest Consensus and Update on Protein Energy-Wasting in Chronic Kidney Disease. Current opinion in clinical nutrition and metabolic care. 2015;18(3):254-62.

21. Convertino VA. Blood volume: Its adaptation to endurance training. Medicine and science in sports and exercise. 1991;23(12):133848.

22. Convertino VA. Blood volume response to physical activity and inactivity. The American journal of the medical sciences. 2007;334(1):729.

23. Mora-Rodriguez R, Sanchez-Roncero A, Fernandez-Elias VE, GuadalupeGrau A, Ortega JF, Dela F, Helge JW. Aerobic exercise training increases muscle water content in obese middle-age men. Med. Sci. Sports Exerc. 2015;21.

24. Mariak Z, Lewko J, Luczaj J, Polocki B, White MD. The relationship between directly measured human cerebral and tympanic temperatures during changes in brain temperatures. European journal of applied physiology and occupational physiology. 1994;69(6):545-9.

25. Lee J, Matsumura K, Yamakoshi K, Rolfe PJ, Tanaka N, Yamakoshi Y, Takahashi K, Kim K, Hirose H, Yamakoshi T. Development of a novel tympanic temperature monitoring system for GT car racing athletes. In IFMBE Proceedings. 2013;39:2062-65).

26. Hilgemann RJ, Garlipp DC, Jacinto G, Caberlon IB, Ross L, Otsuka M, Lopes AL. Análise da desidratação em sujeitos treinados aerobiamente e anaerobiamente em uma aula de bike indoor. RBPFEX-Revista Brasileira de Prescrição e Fisiologia do Exercício. 2016;9(54):438-45.

27. Perrone CA, Meyer F. Avaliação do estado hidroeletrolítico de crianças praticantes de exercício físico e recomendação de hidratação. Revista Brasileira Ciência Esporte. 2011;33(3): 773-86.

28. Alvira JMF, Iglesia I, Pêgo CF, Babio N, Salvadó JS, Moreno LA. Fluid intake in Spanish children and adolescents; a cross-sectional study. Nutricion hospitalaria. 2014;29(5):1163-70.

29. Bergamasco JGP, Benchimol L, Almeida Filho LF, Vargas $P$, Carvalho T, Moraes A. Análise da Freqüência Cardíaca e do VO2 máximo em Atletas Universitários de Handebol Através do Teste do Vai-e-Vem 20 metros. Movimento e Percepção. 2005;5(7):146-63. 